\title{
The Yarumos Eco-Park: Evaluation of its Current Situation with Emphasis on Territorial Accessibility
}

\author{
Diego Escobar ${ }^{1}$, Jorge Montoya ${ }^{1} \&$ Carlos Moncada $^{2}$ \\ ${ }^{1}$ Universidad Nacional de Colombia, Sede Manizales. Facultad de Ingeniería y Arquitectura, Departamento de \\ Ingeniería Civil, Carrera 27 \# 64-60, Manizales, 170004, Colombia \\ ${ }^{2}$ Universidad Nacional de Colombia, Sede Bogotá. Facultad de Ingeniería, Departamento de Ingeniería Civil y \\ Agrícola, Ciudad Universitaria edificio 417 oficina 417, Bogotá, 111321, Colombia \\ Correspondence: Diego Escobar, Universidad Nacional de Colombia, Sede Manizales. Facultad de Ingeniería y \\ Arquitectura, Departamento de Ingeniería Civil, Carrera 27 \# 64-60, Manizales, 170004, Colombia. E-mail: \\ daescobarga@unal.edu.co
}

Received: June 10, 2018

Accepted: June 25, 2018

Online Published: June 26, 2018

doi:10.5539/mas.v12n7p89

URL: https://doi.org/10.5539/mas.v12n7p89

The research is financed by Universidad Nacional de Colombia, Sede Manizales.

\begin{abstract}
The conservation and preservation of sustainable environmental spaces, fosters the integral development of the population, therefore, in this investigation the current situation analysis of Los Yarumos eco-park in Manizales, Colombia, is addressed, taking in account the current challenges, from the interior of the eco-park, aerial tramway, as well as from the territorial accessibility perspective; through the usage of computing tools (ArcMap, Microsoft Excel), facilitating mechanisms for the recovering and repowering of the ecological center. The applied methodology considers the restructuration of the city's traffic network, along with the location and construction of the accessibility turns to the eco-park, complemented with socioeconomic variables for the coverage evaluation.
\end{abstract}

Keywords: accessibility, conservation, los yarumos eco-park, evaluation, restoration, aerial tramway

\section{Introduction}

The development of ecological parks (eco-parks), facilitates the community integration with the environment, guarantying formation on environmental consciousness, and making possible the conservation of the existing fauna and flora, endorsed by the global concerns for the biodiversity loss (Tapan \& Alauddin, 20061); is because of this that the necessity of preserving the current spaces becomes evident, permitting the population enjoyment of the different benefits and attractions offered by them.

Manizales, city that makes part of the so-called Golden triangle of Colombia and capital city of the department of Caldas (Figure 1), is located on one side of the Andean mountain range $5^{\circ} 3$ ' $58^{\prime \prime}$ north latitude and $75^{\circ} 29^{\prime} 05^{\prime \prime}$ west longitude, 2150 mams (Alcaldia de Manizales, 2017); covers $572 \mathrm{~km} 2$ from which 35,11km2 (Gobernación de Caldas, 2017) correspond to an urban area that holds 371.301 inhabitants (Departamento Administrativo Nacional de Estadistica [DANE], 2017). The topography of the city (abrupt type) has marked the urbanistic evolution of the zone, forcing the city's population to adapt to the existing unevenness of the terrain and limiting its expansion (Robledo, 1996; Chardon, 2008).

In the mobility field, the city holds the sustainable means of transportation as the most used, with percentages up to $71 \%$ on daily trips, distributed in public transportation, bicycle and hiking (Manizales Como Vamos, 2017). These percentages suggest the possibility for the city to have a better interaction with the environment, hence making it easy to implement sustainable policies that will influence the integral development of the population.

The city accounts 6 urban eco-parks within the Territorial Ordering Plan 2017-2021 as environmental urban areas of great importance and support for the preservation, restoring or sustainable use of the existence biodiversity, from a public and/or private perspective (Alcaldía de Manizales, 2017). The areas are El Prado Popular Forest Eco-park, Monteleón Forest Eco-park, Central University Eco-park, Alcázares Eco-park, Cerro Sancancio Ecopark, and our case study, Los Yarumos Eco-park. 

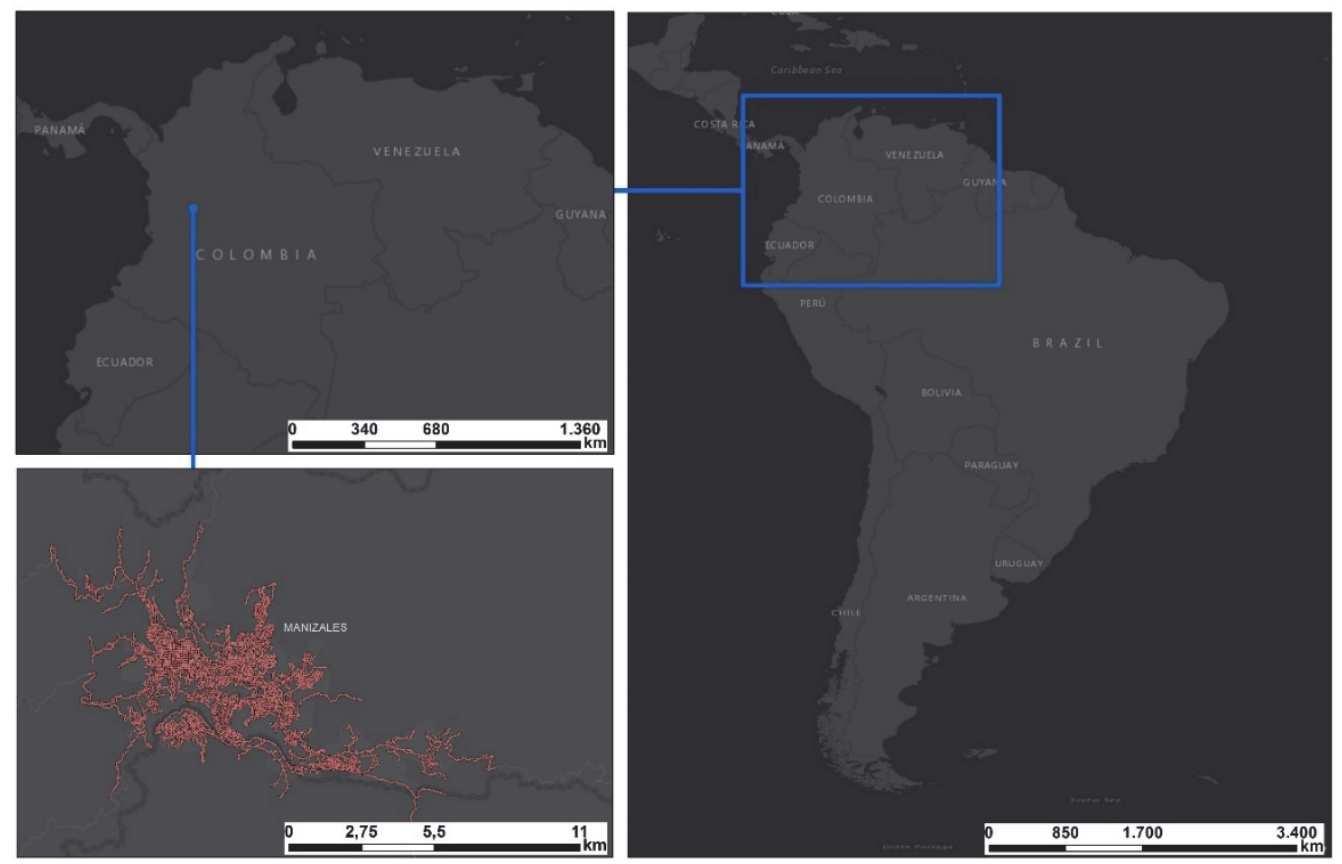

Figure 1. Manizales Geographic Location

The Yarumos Eco-park is located on the north-west region of the city (Figure 2) in Minitas neighborhood; with 100,29 hectare, being the largest urban eco-park (Alcaldía de Manizales, 2017); incorporating a great variety of flora and fauna within its misty forest as possums, foxes, wild cats, bromeliads, orquids, anthuriums, and of course the tree from which the park received its name, "The Yarumo" (Instituto de Cultura y Turismo, 2017).

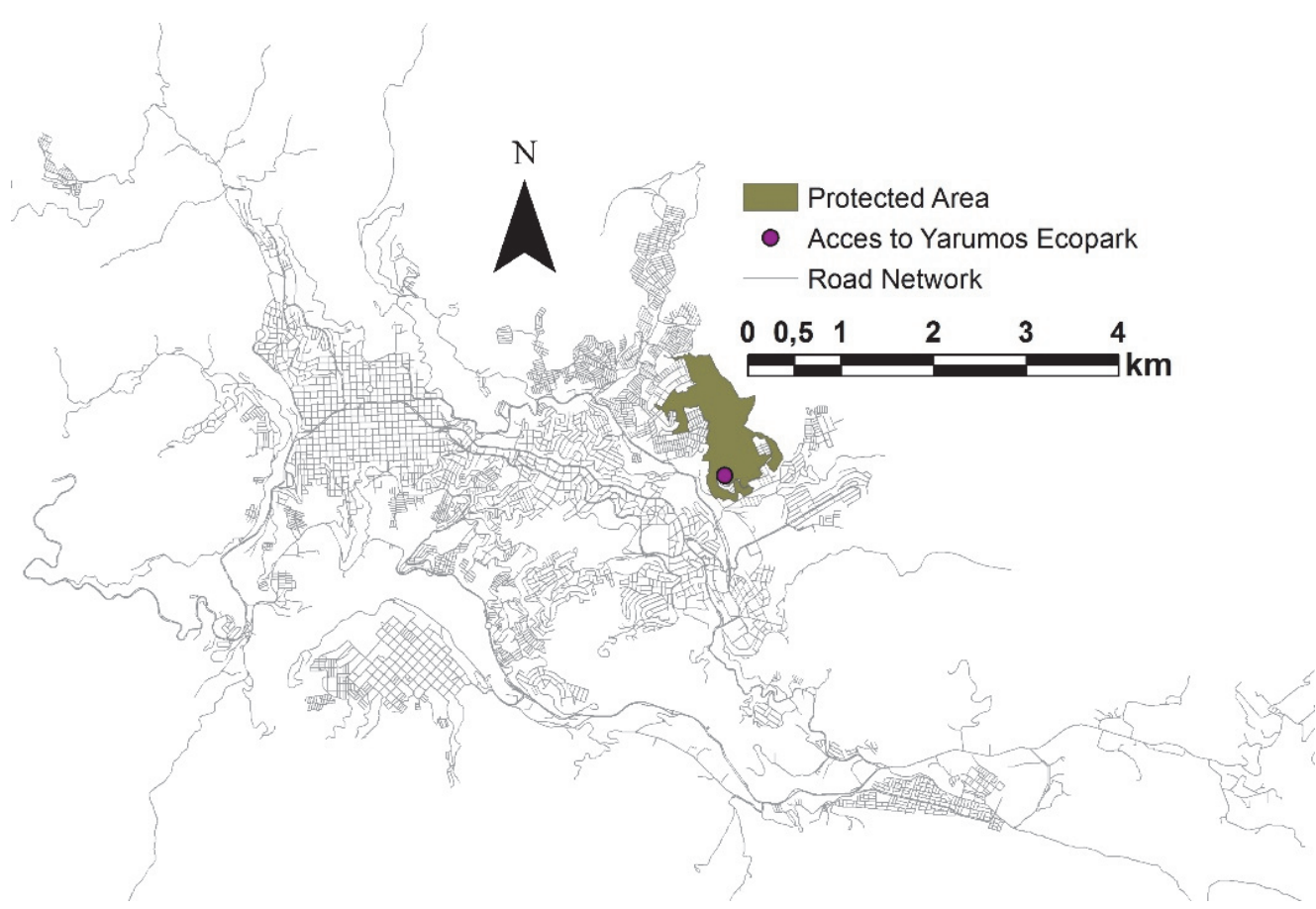

Figure 2. The Yarumos Eco-park Location

The extensive diversity and multiple activities within the eco-park, generate a big appealing for the city, nevertheless, due to low exposure and bad administration throughout time, its infrastructure has been deteriorated, 
limiting its operability and increasing possible accidents risks; thus, it is necessary to evaluate the current conditions of the park, from its interior, as well as from its accessibility in relation to its location. Keeping this in mind, it is recommendable to interiorize the "accessibility" concept with the objective of comprehending in an accurate manner the evaluation results.

The term itself, comprehends the ease by which anything or anyone can accesses without difficulty, nonetheless, in our context, there are some definitions of great weigh like the one given by Hansen in 1959 "The potential of opportunities for interaction" (Hansen, 1959), considerate as the fundamental concept despite the existence of the registry of the term since the second decade of the twentieth century (Batty, 2009). Other definitions imply the relation between human activity forms, including, mobility, communication (Montoya, Escobar, \& Moncada, 2017; Vega, 2011; Geurs \& Van Wee, 2004), from different approaches such as: infrastructure, land usage, location, and the combination of all the previously mentioned.

Some examples of the application of the accessibility in different science fields can be appreciated in: sustainability (Izquierdo, 1994; Escobar, Cadena, \& Salas, 2015), social exclusion (Bocarejo \& Oviedo, 2012; Schürmann, Spiekermann, \& Wegener, 1997), opportunities and services access (wach \& Kumagai, 1973; Calcuttawala, 2006), commerce (Montoya et al, 2017; Zuluaga \& Escobar, 2016), transport planning (Escobar, Tapasco, \& Giraldo, 2015; Monzón de Caceres, 1988; Geurs \& Van Wee, 2004).

\section{Method}

The designated research methodology, is divided in 5 phases (figure 3) like it is described as follows.

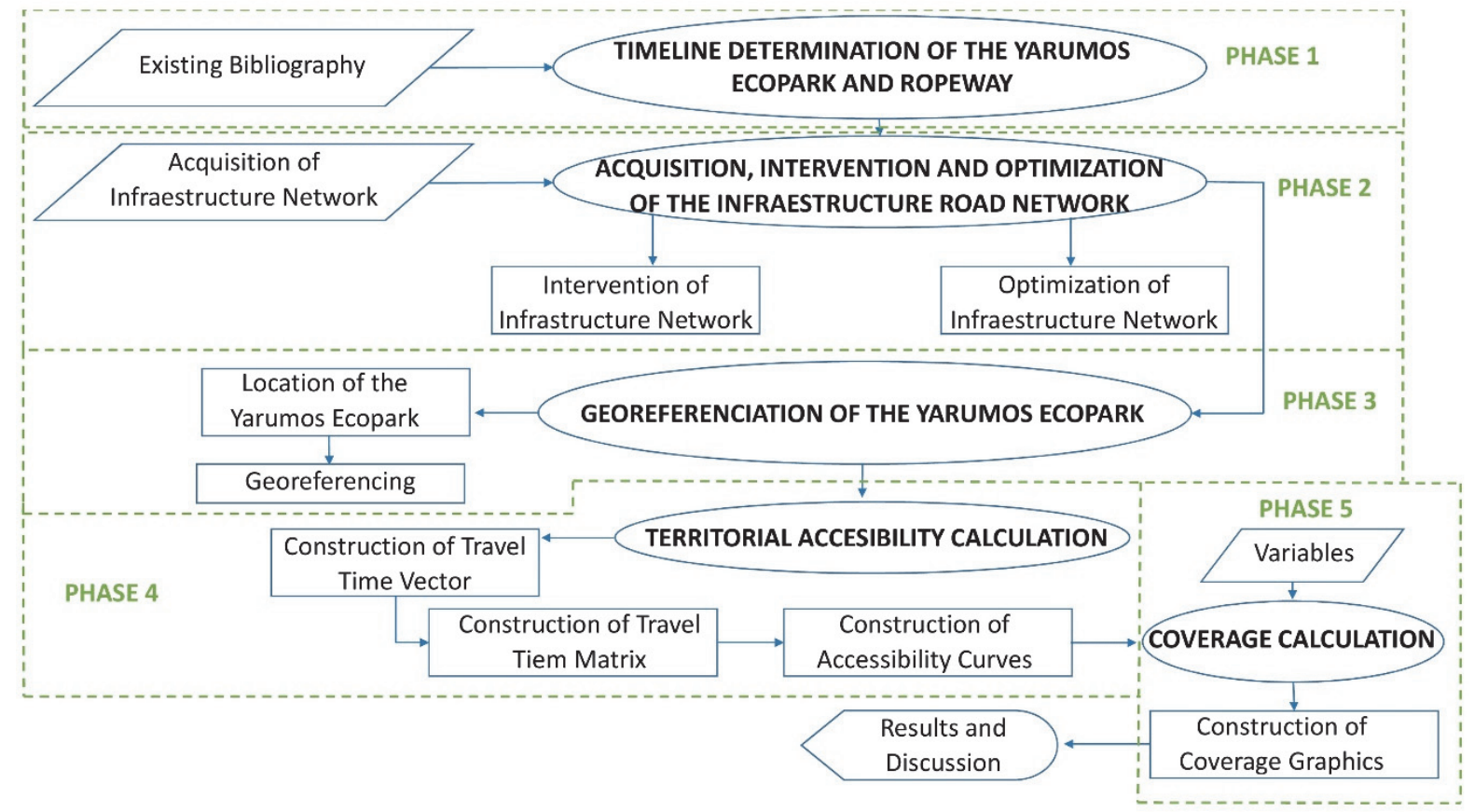

Figure 3. Research Methodology

\subsection{Determination of the Los Yarumos Eco-Park Timeline and its Aerial Tramway}

Making an intensive bibliographic research, the Los Yarumos Eco-park timeline is determined, considering its creation and opening, as well as the implementation of the aerial tramway system and the problems it has presented until the current time.

\subsection{Acquisition, Intervention and Enhancement of the Traffic Network Infrastructure}

Phase 2 contains the acquisition of the traffic network infrastructure and its fine-tuning based on the information obtained from the mobility plan of the city (Alcaldía d eManizales, 2011); this network is made up of 11374 links or arcs (road segments) and 8580 nodes or spots (road intersections, beginning or end of arcs), see figure 4, distributed and located in an specialized way, aside from meeting the physical and technical existing characteristics (speed, length, topology, tread, directionality, among others). 


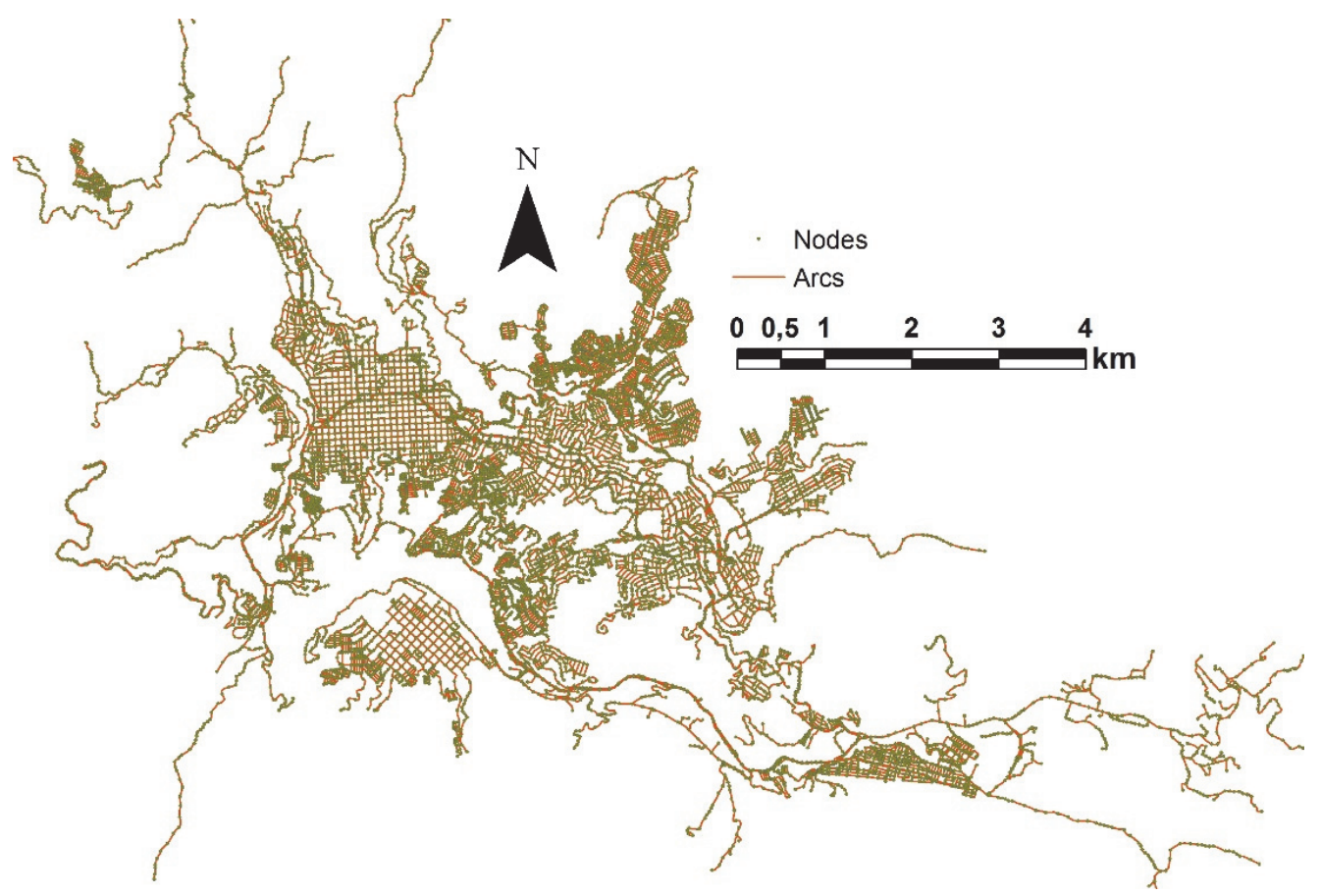

Figure 4. Manizales traffic network infrastructure

After the acquisition of the traffic network, the municipal administration proposed interventions in the 2011-2017 term are made through the «ArcMap» tool, considering directionality, new structures, extensions, etc.; until a scenario meeting similar to reality.

\subsection{The Yarumos Eco-Park Georeferencing}

Once the enhancement and calibration of the traffic network has been made, Los Yarumos Eco-park is located and georeferenced, considering the main access as the contact point of the traffic network.

\subsection{Territorial Accessibility Assessment}

In this methodologic phase, the accessibility curves are constructed by making use of the ArcMap tool, which permits the identification of the access level that the Eco-park possesses, from the other network nodes.

The elaboration of the curves is centered on the construction of the vector of times of travel, which considerate the accumulated value, in time, of traveling on each arc from an origin node $i$ To a destination node $j$ (expression 1). Nevertheless, the construction of the vector of times of travel involves the use of a mathematical algorithm that help to determine the shortest path from the origin node to the destiny one (algorithm Dijkstra); this algorithm is found in the Network Analyst of the ArcMap tool.

$$
T v_{i}=\frac{L_{i}}{V_{i}} \quad i=1,2,3, \ldots, n
$$

The algorithm internal mechanics identifies the shortest path between the origin node $(0)$ and a final node $(F)$, as long as there is a possible connection between them. It is assigned then to each arch $a_{i j}$ a value of $d_{i j}$, the one would be infinite if there is no possible connection between the nodes; later it is denominated $\mathrm{S}$ the set vertexes connected in the interaction in course, to which the vertex of origin 0 is incorporated.

Once the set in constructed, the tags $\mathrm{P}$ are constructed to which the values $P_{0}=0$ y $P_{i}=\infty$ are assigned if $i$ is different than $O$, complementary the variable $t_{i}=O$ is generated. Then it is stablished as $(y)$ to the last vertex incorporated to the set $S$ in such a way that for every z vertex not included in $S$ it is calculated $P_{z}=\min \left\{P_{z}, P_{y}+\right.$ $\left.d_{y z}\right\}$; si $P_{y}+d_{y z}<P_{z}$, it is made $t_{z}=y$, then it is determined $z *$ among all the vertexes $z$ that meet $P_{z^{*}}=$ $\min \left\{P_{z}\right\}$. Si $P_{z}=\infty$ the finding process is finished and it is assumed that there is no finite path length between $O$ and the set $S$ vertexes, otherwise, if there is a connection the process continues and it is incorporated $z *$ to the $S$ set, where $P_{z^{*}}$ will be the value of the minimum distance between $z$ y $O$. At last, if $z$ y $F=z *$ the interaction process is finished, if not, it continues with the (Sallán, Guardiet, \& Suñé, 2010) cycle. 
After the traveling cost for each node is determined, to Los Yarumos Eco-park, the obtained value is related to the geospatial coordinates of each one of them and then construct the minimum traveling times matrix. Afterwards the matrix is processed through ArchMap, using the Geostatical Analyst extension, in which it is found the ordinary Kriging method with lineal semivariogram like a projection model. This projection method considers the spatial dependence between point of the same sample (expression 2) (Perilla, Escobar, \& Cardona, 2018).

$$
\overline{\gamma_{(h)}}=\frac{\sum\left(Z_{(x+h)}-Z_{(x)}\right)^{2}}{2 n}
$$

Where $Z_{(x)}=$ value of the variable in the node of coordinates $\mathrm{s} x, \mathrm{y} ; Z_{(x+h)}=$ next value of the simple at a distance of $\mathrm{h} ; \mathrm{n}=$ number of doubles that are found spaced by the distance $\mathrm{h}$ (Giraldo, 2002).

\section{Coverage assessment}

Finally, the necessary socioeconomic variables are formulated for the coverage assessment, among them we consider population, socioeconomic stratum and area; after the variables are stablished, they are associated to the accessibility turns by means of the ArchMap tool, in its Geoprocessing extension-Intersect. As a result of the association, the percentage ogives are constructed on Microsoft Excel.

\section{Results}

\subsection{Los Yarumos Eco-Park Timeline and its Aerial Tramway}

The Tropical Rainforest Eco-park "Los Yarumos", arises from the need for recreation and tourism spaces in the city of Maizales around the end of the $90 \mathrm{~s}$, considering the lack of correspondence of the quality of the recreational areas of the city in relation to its population. For this reason, in the year of 1999, a group of citizens called "Amigos por Caldas" initiated a citizen awareness process in search of economic and institutional support for the construction of the eco-park; as a result of this, the linking of the LUKER Foundation and the Mayor's Office of Manizales was achieved for the development of the studies and designs, adding the Institute of Financing, Promotion and Development of Projects of Manizales (INFIMANIZALES) and the UNDP as financing entities (Lopéz, Escobar, \& Mejía, 2018)

Thus, in 2002, Los Yarumos Eco-park was delivered to the Manizales people, with a total of 53 hectares of lowland tropical rainforest and a set of high-quality ecological and mechanical attractions. Among the activities to be carried out in the Eco-park we find Canopy, Torrentism, Ecological Trails, Climbing Wall, Museum, Slides on land, among others. (Manizales abierta al deporte, 2017)

For several years the operation of the eco-park met the general expectations, however, near 2009, its operation was affected given the decrease in visitors, in addition to the disconnection with the main transport network and public service routes. It is then when the construction of the aerial tramway system was chosen in order to upgrade the eco-park and improve the connectivity of the users. Other important contributions in the process of recovery and upgrading was the implementation of the BioMa project (Central Hidroelectica de Caldas, 2014) and the incorporation of the Christ made in solid waste by the artist Beimar Alexis Espitia representing the union of the three departments of the coffee region, stating that this "is a symbol for the eco-park to flourish".

Despite the efforts, different events have left the functioning of Los Yarumos Eco-park in a critical condition, being obliged to answer for numerous administrative, fiscal, disciplinary and tributary situations, which leaves large debts and a significant deterioration environment (La Patria, 2012).

The construction of the aerial tramway system of Los Yarumos Eco-park, was proposed by the municipal administration to FONTUR in 2009 and executed in 2011, and developed with the purpose of reducing the access time to the eco-park; starting its operation on December 30th with a total length of 760 meters, 4 cabins, 2 stations and travel time of 4 minutes (Meridiano Informativo, 2011).

As a measure of evolution of the ropeway, a timeline is established with the different events that have taken place to date (figure 5).

Currently, the aerial tramway to Los Yarumos, has completed 6 years without operating, resulting on a dismantling order by the court of litigation on March 21 of the present year, for which it has a period of three months to fulfill the requirement (La Patria, 2018). 


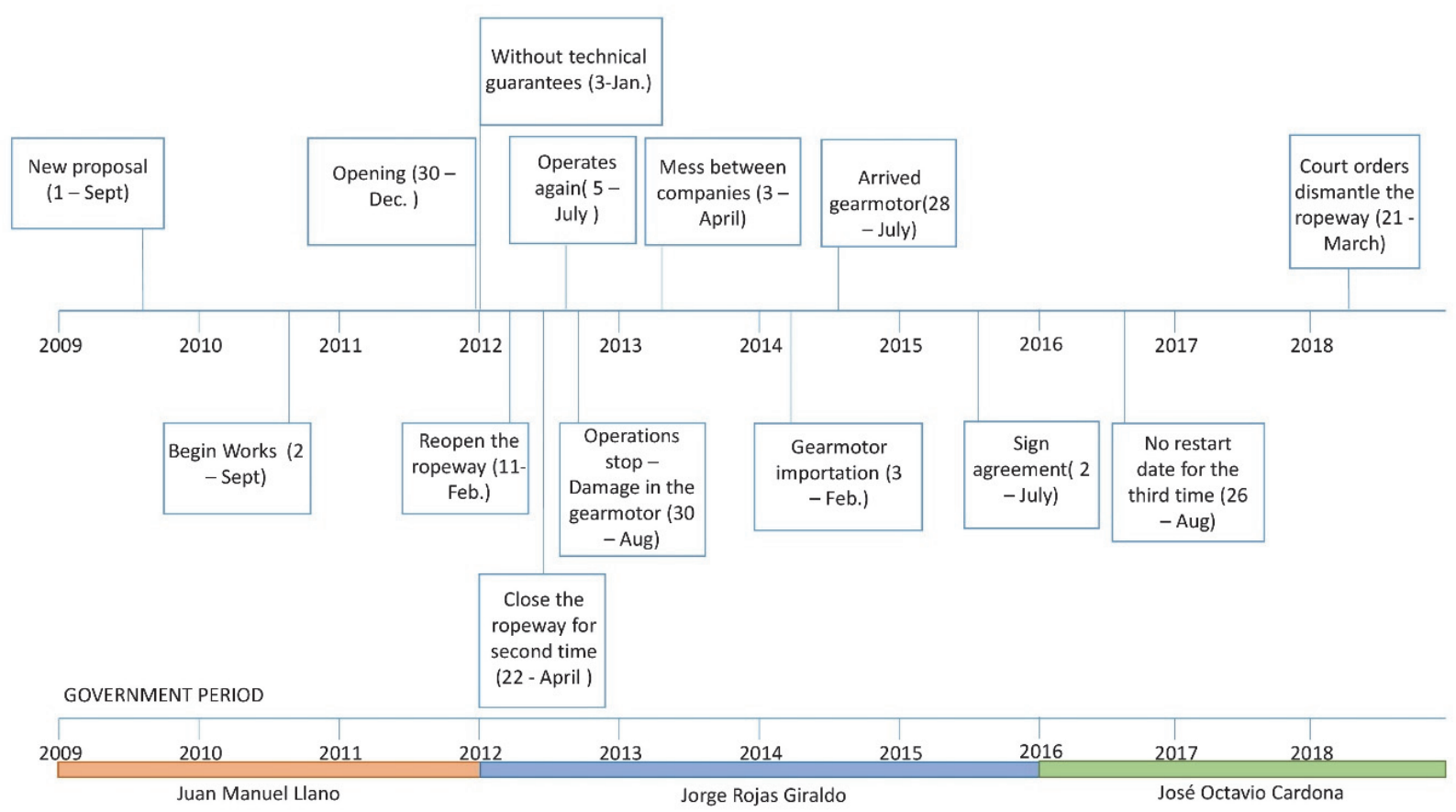

Figure 2. The Yarumos Eco-park Aerial Tramway Timeline

\subsection{Territorial Accessibility Analysis}

As a result of the evaluation of territorial accessibility towards Los Yarumos Eco-park, Figure 6 is presented, where the accessibility curves are shown at 5 minute intervals. It is identified that the center - east sector of the city has the easiest access way to the eco-park with values lower than 30 minutes in traveling time; on the other hand, it is identified that the highest cost of displacement occurs in the north-western part of the city to La Linda sector with an up to 70 minutes value.

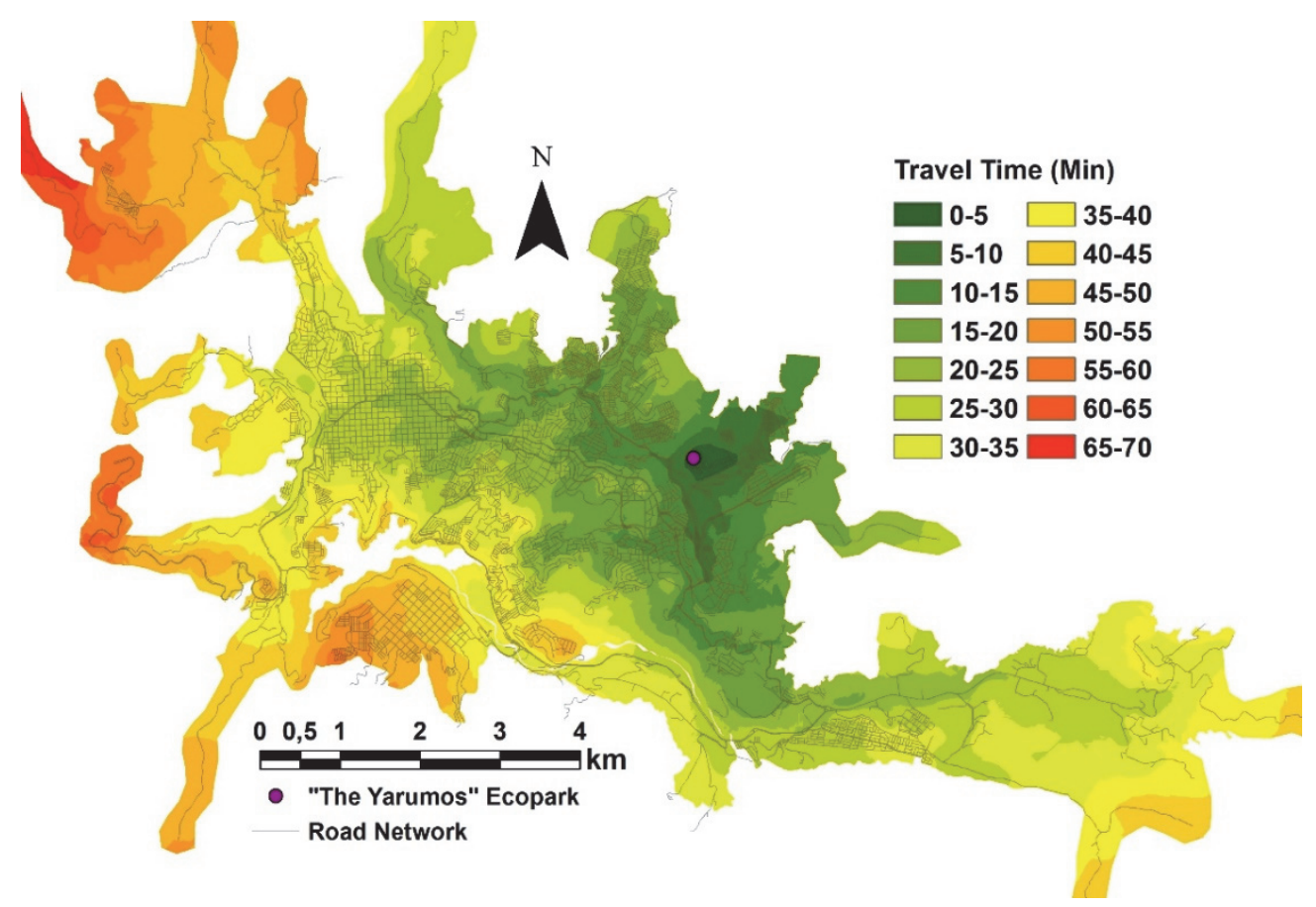

Figure 3. Los Yarumos Eco-park Integral Territorial Accessibility Curves 
Figure 7 shows the results of cumulative coverage by socio-economic stratum generated by Los Yarumos Ecopark, the strata with the best coverage are 5 and 6 , with values higher than $60 \%$ in the shortest travel time at 20 minutes, followed by stratum 2 with $50 \%$ coverage for the same length of time. On the contrary, strata 1, 3 and 4 have the lowest coverage, number 1 having the worst condition, with a coverage of $20 \%$ in a 25 minutes length of time.

Additionally, Figure 8 is shown displaying the percentage of coverage accumulated by population and total area; for a coverage percentage of $50 \%$, a time of 26 and 32 minutes is required respectively; the variation in coverage, presents a maximum separation between curves of $18 \%$, caused by the residence of the citizens in the interior of the city. As a general balance, we can say that the level of access to the eco-park is good, considering that for $90 \%$ of the population the traveling time is less than 45 minutes, this being less than the average traveling time in some cities around the world (Bogotá Como Vamos, 2016; MOOVIT, 2016).

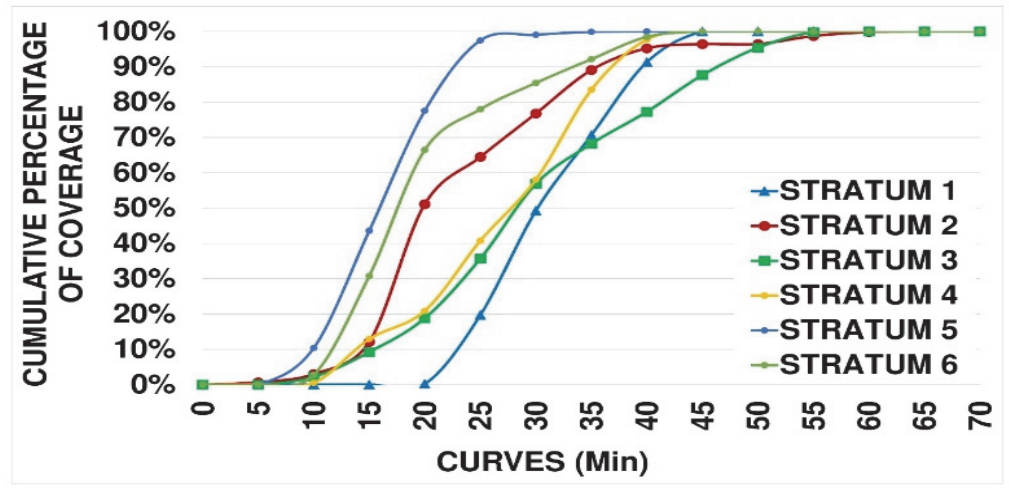

Figure 7. Cumulative Percentage of Coverage by Strata for Los Yarumos Eco-park

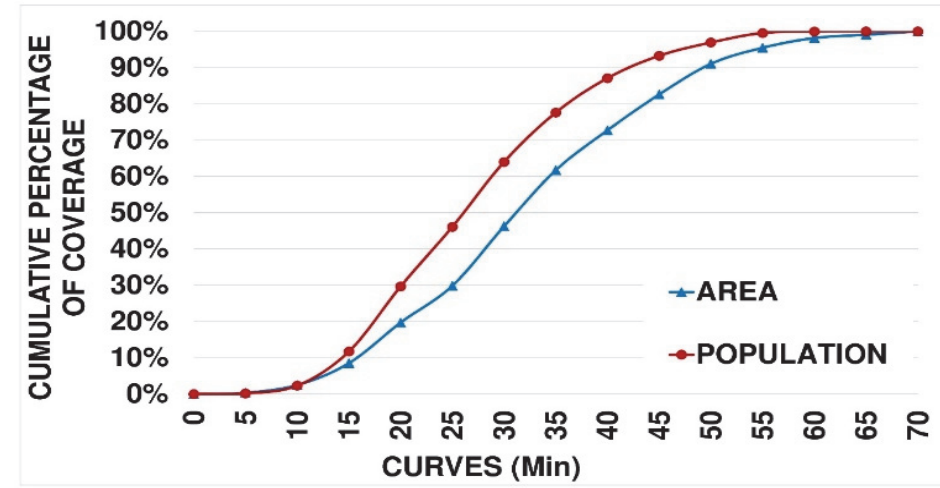

Figure 8. Coverage Percentage by Population and Area for Los Yarumos Eco-park

In order to complement the analysis, to Los Yarumos Eco-park, figure 9 was constructed in which the territorial accessibility curves are shown at a global level for the city of Manizales, as well as the location of the protected area of the eco-park; then there is a separation between curves every 2 minutes, where its lowest value is 20 minutes to the interior of the city and 66 minutes to the north-west. In the case of the eco-park, it could be determined through expression 3 that the average traveling time is 26.5 minutes, which corroborates the ease of access presented in figures 6,7 and 8 .

$$
\overline{T v}=\frac{\sum\left(T v_{i} * A_{i}\right)}{\sum A}
$$




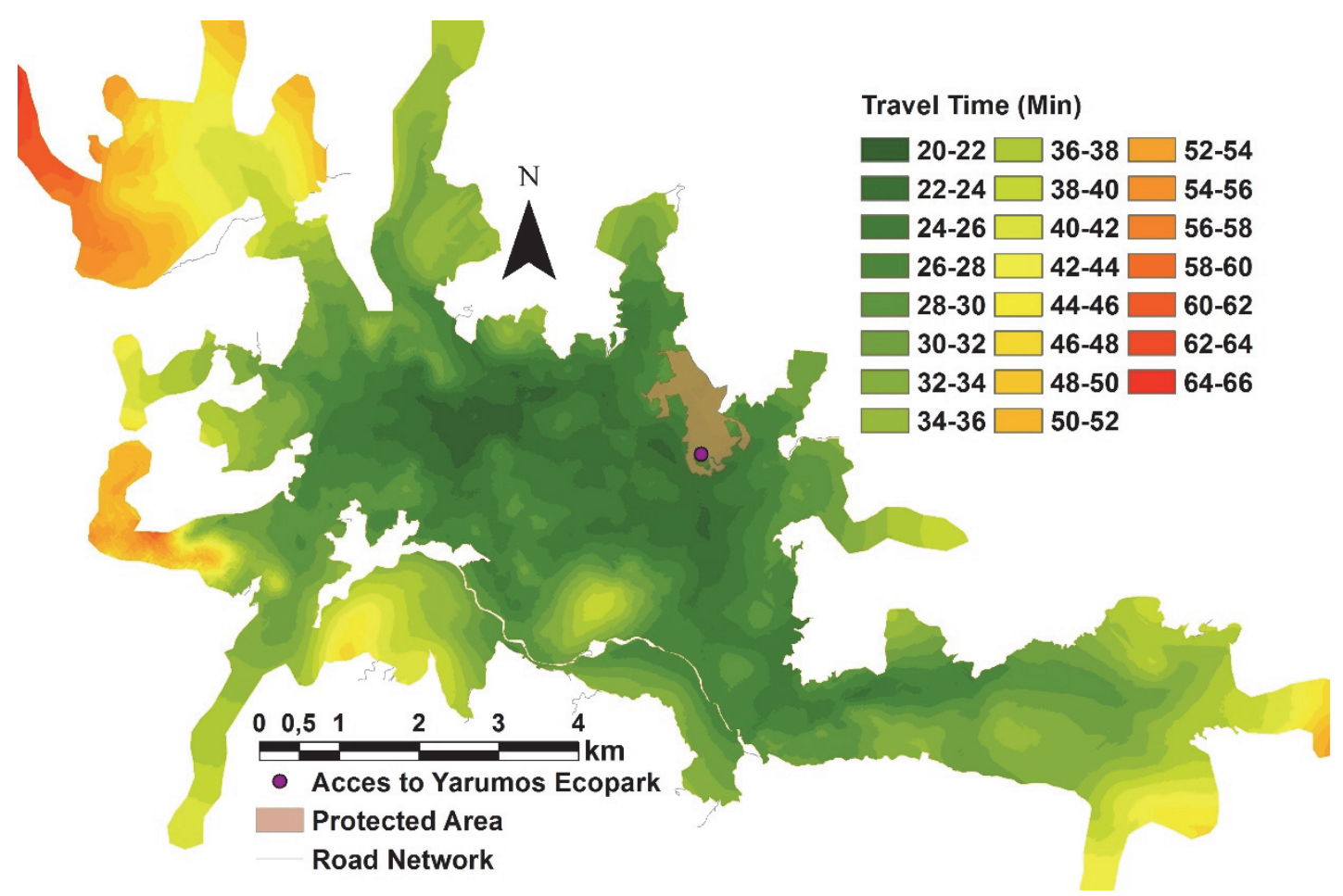

Figure 9. Global Accessibility Curves for Los Yarumos Ecopark

\section{Conclusions}

The evaluation of the accessibility to Los Yarumos, evidences that, the location of the eco-park is sufficiently attractive for society, given the travel time with which it is covered (around 35 minutes for $80 \%$ of the population); This result can be considered for the implementation of possible transport routes to the eco-park, encouraging the use of the ecotourism center, as well as improving the mobility conditions of the visitors.

It is necessary to opt for the reactivation and renewal of the eco-park, as an element of integral development and conservation of the environment, achieving a high impact on the population, thus guaranteeing a better quality in the recreation areas for the citizens. This renewal should consider the different difficulties and administrative problems that currently deteriorate the ecological center, in order to overcome the crisis and avoid future problems according to current experience.

The recovery of the aerial tramway would be a favorable option in the upgrading of the eco-park, however, given the decision made by the contentious court of Manizales, the dismantling of the structure must be carried out. In the future, the analysis of a restructuring of the cable tramway system could be made, considering the current shortcomings, as well as new technologies in order to guarantee optimal operation and an intermodal connection of the station.

There is evidence of a lack of commitment on the part of the municipal administration, taking into account that, during 3 periods of government, there was no solution to the problem of the eco-park and specifically to the case of aerial tramway cable.

\section{Acknowledgments}

The authors express their sincere thanks to the students linked in the research groups Urban Planning and Sustainable Mobility of the National University of Colombia, Manizales headquarters; as well as engineers Santiago Cardona and Diego Julián Perilla.

\section{References}

Alcaldía de Manizales (2011). Plan de Movilidad de la ciudad de Manizales 2010 - 2040. Secretaría de Tránsito y Transporte, Universidad Nacional de Colombia - Sede Manizales, Manizales, Colombia.

Alcaldía de Manizales (2017). Plan de Ordenamiento Territorial de Manizales 2017-2031. DTS Urbano, Manizales. 
Alcaldía de Manizales. (2017). Información General. Retrieved from http://www.manizales.gov.co/Contenido/Alcaldia/24/informacion-general.

Batty, M. (2009). Accessibility: In search of a unified theory. Environment and Planning B: Planning and Design, 36(2), 191-194. http://doi.org/10.1068/b3602ed

BCV (2016). Bogotá Como Vamos, La movilidad en Bogotá, un compromiso. Retrieved from $\mathrm{http}$ //www.bogotacomovamos.org/blog/la-movilidad-en-bogota-un-compromiso/

Bocarejo, J. P., \& Oviedo, D. R. (2012). Transport accessibility and social inequities: A tool for identification of mobility needs and evaluation of transport investments. Journal of Transport Geography, 24, 142-154. http://doi.org/10.1016/j.jtrangeo.2011.12.004.

Calcuttawala, Z. (2006). Landscapes of information and consumption: A location analysis of public libraries in Calcutta. In Edward D. Garten, Delmus E. Williams \& James M. Nyce (Ed.), 24, 319-388.

Chardon, A. C. (2008). Reasentamiento y hábitat en zonas urbanas, una reflexión en Manizales. Cuadernos de vivienda y urbanismo, 1(2), 226-247.

CHEC (2014). Central Hidroeléctrica de Caldas. Algo bueno pasará en el Ecoparque los Yarumos BioMa "Otra forma de ver", Boletin de Prensa $\mathrm{N}^{\circ} 26$

DANE (2017). Departamento Administrativo Nacional de Estadística. Proyecciones de población total por sexo y grupos de edad de 0 hasta 80 y más años (2005 - 2020). Retrieved from https://www.dane.gov.co/index.php/estadisticas-por-tema/demografia-y-poblacion/proyecciones-depoblacion

Escobar, D. A, Cadena, C., \& Salas, A. (2015). Cobertura Geoespacial de nodos de actividad primaria. Análisis de los aportes a la sostenibilidad urbana mediante un estudio de accesibilidad territorial. Revista EIA, 12(23), 13-27. http:/dx.doi.org/10.14508/reia.2015.12.23.13-27.

Escobar, D. A., Tapasco, O. A., \& Giraldo, J. A. (2015). Medición de Desempeño del Sistema de Transporte Cable Aéreo de la Ciudad de Manizales en Colombia, usando Tres Enfoques: Analítico, Simulado y de Accesibilidad Urbana. Información Tecnológica, 26(6), 199-210. http://dx.doi.org/10.4067/S071807642015000600020 .

Geurs, K. T., \& Van Wee, B. (2004). Accessibility evaluation of land-use and transport strategies: review and researchh directions. Journal of Transport Geography, 12(2), 127-140. http://dx.doi.org/10.1016/j.jtrangeo.2003.10.005

Giraldo R. (2002). Introducción a la geo estadística: Teoría y aplicación. Universidad Nacional de Colombia, Colombia, Bogotá, Colombia.

Gobernación de Caldas. (2017). Fondo para el Financiamiento del Sector Agropecuario, FINAGRO, Biblioteca Luis Ángel Arango del Banco de la República, Datos del Departamento de Caldas. Retrieved from https://goo.gl/tZc2fh

Hansen, W. (1959). How accessibility shapes land use, Journal of the American Institute of Planners, 25(2), 7376. http://dx.doi.org/10.1080/01944365908978307

Instituto de Cultura y Turismo. (2017). Ecoparque los Yarumos. Retrieved from http://culturayturismomanizales.gov.co/yarumos.php

Izquierdo, R. (1994). Transportes, un enfoque integral. Madrid: Servicio de Publicaciones del Colegio de ingenieros de Caminos, Canales y Puertos.

La Patria. (2012). Se enreda la Corporación Los Yarumos con auditoría de la Contraloría de Manizales. Retrieved from http://www.lapatria.com/manizales/se-enreda-la-corporacion-los-yarumos-con-auditoria-de-lacontraloria-de-manizales-12229

La Patria. (2018). Tribunal ordena desmontar Cable a Los Yarumos. Retrieved from http://m.lapatria.com/manizales/tribunal-ordena-desmontar-cable-aereo-los-yarumos-manizales-413278

López I., Escobar D., \& Mejía M. (2018). Success Factors and Lessons Learned from the Management of a PublicPrivate Partnership (PPP) in a Protected Area in Manizales - Colombia. Contemporary Engineering Sciences, 11(20), 959 - 972. HIKARI Ltd, www.m-hikari.com. https://doi.org/10.12988/ces.2018.8259

Manizales Abierta al Deporte. (2017). Ecoparque los Yarumos. Retrieved from https://deporteyrecreacion.wordpress.com/ecoparque-los-yarumos/ 
MCV (2017). Manizales Como Vamos. Movilidad. Retrieved from http://manizalescomovamos.org/wpcontent/uploads/2017/08/Cap\%C3\%ADtulo-8.pdf

Meridiano Informativo (2011). Comenzó socialización para usuarios del Cable Aéreo Los Yarumos. Retrieved from https://meridianoinformativo1390.wordpress.com/2011/05/17/comenzo-socializacion-para-usuariosdel-cable-aereo-los-yarumos/

Montoya, J., Escobar, D., \& Moncada, C. (2017). Proposed location of new shopping centers, application of an urban territorial accessibility analysis. Revista Espacios, 38(51), 4. Retrieved from http://www.revistaespacios.com/a17v38n51/17385104.html

Monzón de Cáceres, A. (1988). La Accesibilidad individual como elemento de evaluación de los planes de transporte en la comunidad de Madrid/España. Informes de la Construcción, 40(396), 21-39.

MOOVIT (2016). Reporte global sobre el uso del transporte público en la ciudades. Retrieved from https://www.company.moovit.com/public-transit-usage-report-2016.

Perilla J., Escobar D., \& Cardona S. (2018). New transportation infrastructure impact in terms of global average access - intersection "la carola" manizales (colombia) case study. Contemporary Engineering Sciences, Hikari, 11(5), 215-227. https://doi.org/10.12988/ces.2018.812

Robledo, J. (1996). La ciudad de la colonización antioqueña. Editorial Universidad Nacional de Colombia. Manizales. pp.146.

Sallán, J., Guardiet, J., \& Suñé, A. (2010). Métodos cuantitativos de organización industrial I, Barchelona: Ediciones de la Universidad Politécnica de Catalunya, p.159

Schürmann, C., Spiekermann, K., \& Wegener, M. (1997). Accessibility indicator, SASI Deliverable D5, Report to the European Commission, Berichte aus dem Institut für Raumplanung, 39, Dortmund.

Tapan, K. N., \& Alauddin (2006). Sitakunda Botanical Garden and Eco-park, Chittagong, Bangladesh: Its impacts on a rural community. The International Journal of Biodiversity Science and Management, 2(1), 1-11.

Vega, A. (2011). A multi-modal approach to sustainable accessibility in Galway. Regional Insights, 2(2), 15-17. https://doi.org/10.1080/20429843.2011.9727923.

Wachs, M., \& Kumagai, T. G. (1973). Physical accessibility as a social indicator. Socio-Economic Planning Sciences, 7(5), 437-456. https://doi.org/10.1016/0038-0121(73)90041-4.

Zuluaga, J. D., \& Escobar, D. (2016). Geomarketing Analysis for Shopping Malls in Manizales (Colombia). Accessibility approach methodology. Revista Espacios, 38(21), 20. Retrieved from http://www.revistaespacios.com/a17v38n21/17382120.html

\section{Copyrights}

Copyright for this article is retained by the author(s), with first publication rights granted to the journal.

This is an open-access article distributed under the terms and conditions of the Creative Commons Attribution license (http://creativecommons.org/licenses/by/4.0/). 